\title{
Review
}

\section{Scientific Aspects of the Study of Transcontinental Relations and Global Settlement}

\author{
Vladimir Spiridonov ${ }^{1}$, Salavat Shabiev ${ }^{2}$ and Sergei Aliukov ${ }^{2, *(1)}$ \\ 1 Russian Academy of Architecture and Construction Sciences, Lenina Ave. 50a, 620075 Yekaterinburg, Russia; \\ sv-abyss@mail.ru \\ 2 Institute of Engineering and Technology, South Ural State University (National Research University), \\ Lenina Ave. 76, 454080 Chelyabinsk, Russia; shabievsg@susu.ru \\ * Correspondence: dimaakv@yandex.ru
}

Citation: Spiridonov, V.; Shabiev, S.; Aliukov, S. Scientific Aspects of the Study of Transcontinental Relations and Global Settlement. Land 2022, 11, 342. https://doi.org/10.3390/ land11030342

Academic Editor: Fabrizio Battisti

Received: 2 February 2022

Accepted: 21 February 2022

Published: 25 February 2022

Publisher's Note: MDPI stays neutral with regard to jurisdictional claims in published maps and institutional affiliations.

Copyright: (C) 2022 by the authors. Licensee MDPI, Basel, Switzerland. This article is an open access article distributed under the terms and conditions of the Creative Commons Attribution (CC BY) license (https:// creativecommons.org/licenses/by/ $4.0 /)$.

\begin{abstract}
A critical review of urban planning scientific aspects of the study of the globalization of settlement systems, including the impact of cross-border and transcontinental links on global urban and interethnic integration and communication processes, is presented. A brief description of the evolution of antagonistic urban planning concepts of studying the trends in the organization and development of macro-regional and global forms of settlement, their interrelationships, and interdependencies, as well as an analysis of the impact of these concepts on the formation of global communication relations, is given. Urban planning is defined as an interdisciplinary science of complex forecasting and planning of world settlement systems and their elements. The interrelation of the seven "principles-compromises" as urban planning principles of ensuring a sustainable balance in the interests of present and future generations is presented. Two urban planning methods of conflict resolution within the framework of the problem under consideration are proposed, based on the modeling of territories of partnership relations and the formation of global settlement based on the development of the uniqueness of territories.
\end{abstract}

Keywords: global settlement systems; cross-border and transcontinental relations; integration and communication processes; modeling of global urban and environmental development; principles-compromises; sustainable balance; methods of conflict resolution

\section{Introduction}

1.1. Development of Scientific Concepts and Approaches in the Field of Urban Planning to Study the Problems of Globalization of Settlement Systems

The exponential growth of the world's population, accelerating processes and conflicts of globalization of world markets, global migration processes, common threats of a natural and climatic nature, technological and technical infrastructure, and telecommunication progress actively affect the change of settlement systems.

Methodological foundations of the study of trends in the globalization of settlement systems have been actively studied since the 1950s of the 20th century. The founders of this scientific movement are urban planner Konstantinos Apostolou Doxiadis [1,2] and economic geographer Jean Gottman [3-5] with their theories of ecumenopolis and megalopolis or megaregion. The concept of supra-agglomeration forms of settlement was developed in the works of researchers such as J.G. Papaioannou [6]; B.J.L. Berry, F.E. Horton [7]; T. Hagerstrand (the modern spatial expansion theory) [8]; J. Song (the concept of the "city-region") [9]; Y. Zhou (the concept metropolitan inter-locking region or MIR) [10]; T.G. McGee (the concepts "desakota" and "extended metropolis") [11,12]; K. Lynch (the concept of the dispersed metropolis) [13]; N.S. Ginsburg, B. Koppel, and J. R. Borchert [14]; S. H. Putnam [15]; M. Wade (the concept "international megalopolis") [16]; R.H. Weller [17]; and others. At the same time, along with the term megalopolis, synonymous concepts 
such as "super-agglomeration", "megaregion", "supra-agglomeration spatial systems", "mega-agglomerations", and "united metro-area" began to be actively used.

Despite the emergence of a scientific direction as ekistics, introduced by K. Doxiadis in the 1960s, as well as the active study of supra-agglomeration and continental processes of urbanization by economic geographers and sociologists, predictive models of the spatial development of such forms of settlement today are antagonistic. At the same time, the formation of major territorial urbanized systems such as "BosWash" (BostonWashington), "ChiPitts" (Chicago-Pittsburgh), and "SanSan" (San Diego-San Francisco) in the USA; "Tokaido" (Tokyo-Osaka) in Japan; "Lon-Liv" (London-Liverpool) and "Rhenish" (Randstad-Rhine-Ruhr-Rhine-Main) in Western Europe; "San-Rio" (Sao Paulo-Rio de Janeiro) and "La-Plata" (La-Plata area) in South America; "Nile" (Cairo-Alexandria) and "Lag-Ib" (Lagos-Ibadan) in Africa; "Jing-Jin-Ji" (Beijing-Tianjin-Hebei) and "Yangtze River Delta" ( Shanghai- Guangzhou) in China; and many others. Today, dozens of similar megalopolises have been identified on all continents of the world.

The works of the following modern researchers are devoted to the study of megaregions: J. R. Short [18]; K. E. Haynes [19]; C. Fang и D. Yu [20]; Y. Kanemoto and K. Tokuoka [21]; A.J. Scott (the concept "global city-region") [22]; W. Zhang (the concept "greater metropolitan belt") [23]; W. Loibl, G. Etminan, E. Gebetsroither-Geringer, and H-M Neumann (the concept "unified metro area") [24]; H. Honermann, R. Witter, and I. Scherrer [25]; D. Morley, A. Rao, C. Ross, and J. Pena [26]; I.M. Moisseev (the concept "mega-agglomerations") [27]; T.Z. Ziyatdinov (the concept "cross-border mega-agglomerations") [28]; E. Baigent [29]; R. Morrill [30]; and others.

Since the 1960s-1970s, with the development of the scientific direction "Theory of Systems" and socio-ecological trends in urban planning, concepts of the regulated spatial development of large and largest forms of settlement, as well as their connections, alternative to the ideas of disordered growth of agglomerations and their systems have been actively discussed. Soviet researchers such as A. Baburov, A. Gutnov, A. Ikonnikov, I. Lezhava, S. Sanok, and others played a special role in this direction [31-35].

A new wave of scientific works of the 1980s and 1990s devoted to the study of predictive models of the spatial organization of world settlement is associated with the socioeconomic prerequisites of globalization processes and, as a consequence, with the promotion of the concept of "world cities" or "global cities". Its founders are researchers in the field of global economics and politics such as Peter Hall [36], George Friedman (the concept of the "new international division of labor") [37,38], and Saskia Sassen (the concept of a "transnational urban system") $[39,40]$. This concept was further developed in the works of P.J. Taylor and R. Aranya, R.E. Lang, B. Derudder, F. Witlox, J.V. Beaverstock, R.G. Smith, G. Catalano, and D.R.F. Walker [41-48]; D. Bronger [49]; M. Pacione [50]; J. Robinson (the concept of "dissimilar cosmopolitanism") [51,52]; P. Marcuse and R. Van Kempen (the concept "globalizing city") [53]; E.F. Isin (the concept of "cosmopolis") [54]; Lo Fuchen and Yeung Ye-man (the concept of the "functional system of the world city") [55]; J.R. Short and Y-H. Kim (the concept of the "global urban network") [56]; M. Castells (the concept "network society") [57,58]; R.G. Smith [59]; and many other authors.

It has also been widely used in the research of world economic processes by statistical centers such as "Globalization and World Cities" (GaWC, at Loughborough University) [60] or the international consulting company Kearney [61]. At the same time, the GaWC research group led by P.J. Taylor [62] in the framework of studying the phenomenon of world cities today attracts international experts such as J.V. Beaverstock, R.G. Smith, B. Derudder, S. Sassen, M. Castells, P. Hall, and J. Friedmann.

Simultaneously with the development of concepts for studying morphology and other urban aspects of global urbanization, the issues of increasing global threats and conflicts related to the processes of settlement globalization are becoming increasingly important in scientific research, including in the works of J. Stadelbauer (Megacities as a Conflict Space) [63]; V.A. Achkasov ("Global Cities" Facing the Challenges of Globalization) [64]; F. Kraas 
(Megacities as Global Risk Areas) [65]; A. Churchill, J.P. Lea, and J.M Courtney (Cities in Conflict) [66]; M. Pelling (The Vulnerability of Cities) [67]; and other authors.

In this connection, it is necessary to resolve these threats and conflicts, taking into account the sustainable development of emerging interethnic megalopolises (macroregions) and rapidly developing "global cities", as well as communication and distribution infrastructures as "pulling" each other's centers of attraction for the processes of urbanization and global socio-economic communications.

\subsection{The Degree of Study of the Influence of Cross-Border and Transcontinental Connections on Global Urban and Interethnic Processes}

A significant role in the study of global settlement is played by cross-border and transcontinental transport and engineering pipeline connections as the framework of the global economy and the settlement system formed by socio-economic macro-regions (megaregions) and urban agglomerations. Thus, the creation of a unified system of transport corridors (road, rail, air, water, sea, pipeline) on the territory of Eurasia is the basis for the further development of not only global supply chains of goods between China, the European Union, the Asia-Pacific macroregion, and the globalization of world markets but also an incentive for sustainable socio-economic and natural-ecological development of the entire continent [68] and inter-ethnic forms of settlement.

To date, a number of strategic documents of the Commonwealth of Asian and European countries, the countries of the American continent, world scientific research, official analytical reports, publications and reviews of financial institutions, research centers, and industry organizations are devoted to the topic of cross-border relations [68-75]. It should also be noted that there are a large number of research publications on this topic, including I. Makarova, K. Shubenkova, V. Mavrin, P. Buyvol, L. Gabsalikhova, and E. Mukhametdinov [76]; M.B. Regmi and S. Hanaoka [77]; R. Šakalys and N. Batarlienè [78]; P.W. de Langen, D.M. Lases Figueroa, K.H. van Donselaar, and J. Bozuwa [79]; and M. SteadieSeifi, N.P. Dellaert, W. Nuijten, T. Van Woensel, and R. Raoufi [80]. However, these works are aimed at developing the potential of transit transport and other forms of transport communications, which does not adequately regulate the issues of sustainable urban development of the global settlement system and the safe integration of different countries into this system. Despite the vastness of such strategic programs and projects, they are segmental, specialized, or departmental in nature.

The study of the globalization of settlement is based on the provisions of the direct dependence of the form of spatial urbanization and the relations between these urban planning systems. Nevertheless, they are extremely rarely reflected in research papers and do not determine the form and types of such dependence. This is due to the diversity of development concepts and statistical approaches to the study of the settlement itself and the specifics of strategic tasks for the development of transcontinental transport and engineering communications. Nevertheless, the scientific and specialized isolation of the study of these processes can negatively affect the solution of the fundamental tasks of sustainable development of the settlement of the world for a distant period. In this connection, it is important to consider the need for future research activities within the framework of this issue.

We should note a number of scientific research works aimed at studying the problems of the relationship between forms of urbanization and transnational or interregional transport corridors. These include the works of L. Albrechts, T. Tasan-Kok, T. Coppens, J. De Vries, H. Priemus, and S. Singh (the concept "mega-corridors") [81-84]; C. Pell (the concept "supermobility") [85]; M. Castells (the concept "informational city") [86]; L. Tian and Y. Zhang (the concept "mega city-regions") [87]; I. Tonkoy and O. Inshakova (the concept "information and transport connectivity of settlement objects and urban clusters of various taxonomic levels") [88]; and others. 


\subsection{The Purpose, Main Objectives, and Methodology of the Study}

The modern theory of urban planning is based on the provisions of the direct dependence of the development of large and largest settlement systems as socio-economic regions and macro-regions on the connecting them and their centers-agglomerations of arteries in the form of transport and engineering communications. Thus, transport and engineering routes (automobile, railway, sea, river, air, and pipeline) form the global framework of global settlement.

The few scientific works devoted to urban planning issues of the formation of global settlement systems are based on opposite hypotheses. Some consider the organization of a continuous grid or strip form of global settlement along waterways and land transport corridors. Others justify transnational communications as a connecting and integration framework between rapidly developing macro-regions or megalopolises. Still, others, on the contrary, are focused on studying the development of global settlement and the corresponding system of relations from the perspective of the absorption of surrounding economic and urban resources by continuously growing world centers-agglomerations. However, each of these hypotheses allows us to draw conclusions about the direct dependence of the development of transcontinental ties and the world settlement itself. At the same time, the framework of such connections should differ, taking into account different concepts of the development of settlement forms.

Taking into account the above, the main purpose of this study is to analyze the impact of the concepts of urban development of the global settlement system on modern strategic programs and projects for the formation of a network of cross-border and trans-continental corridors. In order to achieve this goal, the authors consider it necessary to conduct a critical review of the evolution of the world experience in forecasting globalization, the development of settlement systems, and the planning of global transport arteries within the framework of models of these concepts; determination of the interrelationships of existing strategic programs and projects for the development of cross-border and trans-continental ties and concepts of world forms of settlement; and definition of urban planning scientific aspects of forecasting, planning, and management of the development of complex global urban processes, taking into account transport infrastructure.

The methodology of the work is based on the consistent use of methods of comparative analysis of the concepts of urban development of the global settlement system, taking into account the formation of a framework of transcontinental connections, as well as graphical comparison (modeling) of these concepts and transcontinental corridors included in the main programs and projects of global transport development. Separate principles and aspects of historical-logical and systemic approaches are used in the framework of a critical review of the evolution of antagonistic urban planning concepts, the study of trends in the organization and development of macro-regional and global forms of settlement, their interrelations, and interdependencies.

The sources of this research are the main author's concepts of the development of world settlement systems, some alternative concepts of globalization, important from the perspective of urban planning issues, significant modern statistical analytical data on the issue under consideration, and existing strategic programs and projects for the development of a network of transcontinental transport links (in open access), including graphic materials presented in these data.

\section{A Critical Review of the Evolution of the Main Concepts of Spatial Forms of World Urbanization, Taking into Account the Framework of Transcontinental Transport Links}

In order to study the possible forms and types of interdependence of world settlement and the framework of transcontinental relations, a critical review of the evolution of the concepts of globalization of settlement systems is conducted, as well as other scientific urban planning aspects of the development of global urbanization are considered. 


\subsection{Concepts of Network Forms of Settlement}

Thus, in his work Ecumenopolis: Tomorrow's City 1968 [1,2], K. Doxiadis presented a continuous "planetary city" in the form of a linear system of settlement along the coast of the world's oceans and major waterways, which should be the result of global urbanization on the planet. At the same time, according to the theory of ekistics, the process of world urbanization should go from the monocentric form of settlement of dinapolis to dynametropolis or the system of dinapolis, then to dynamegalopolis and ecumenopolis (Figure 1). Such a ribbon form of global settlement implies continuous transport doublers along waterways, virtually excluding the netted intra-continental structure of connections.

a

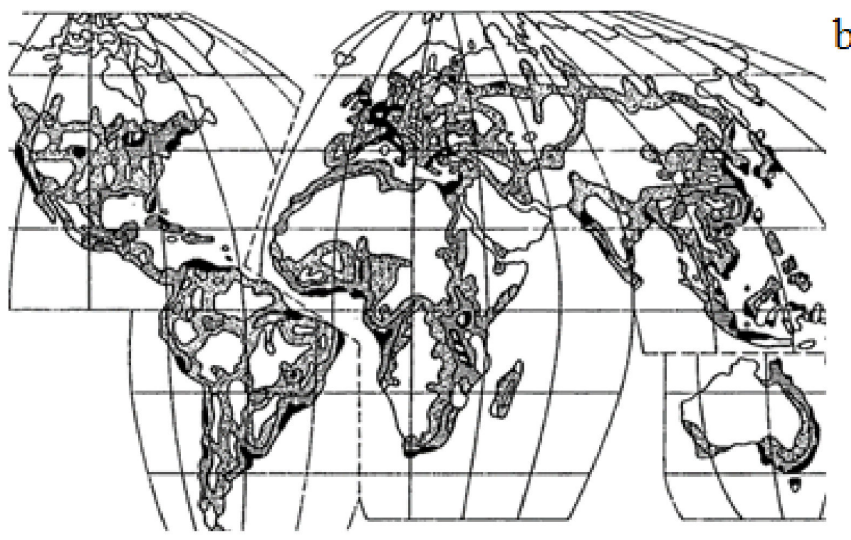

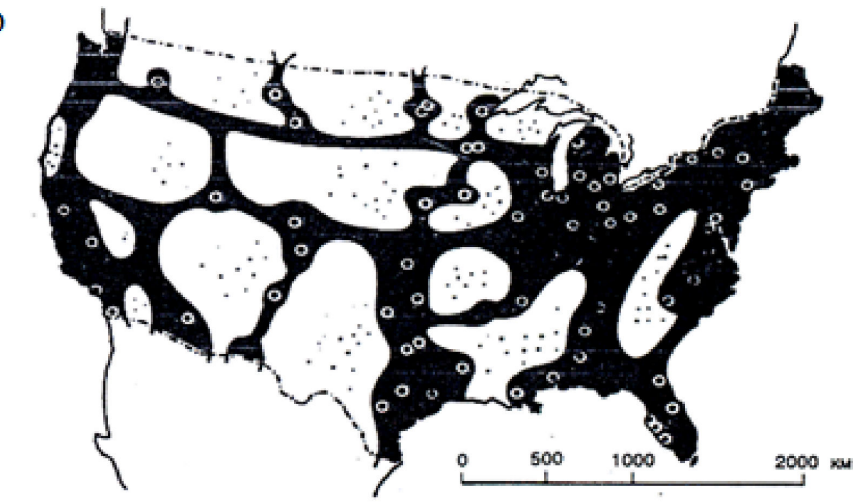

Figure 1. (a) Earth's Ecumentopolis (forecast for 2100), according to K. Doxiadis [1,2]; (b) Ecumenopolis in the United States (forecast for 2060), according to K. Doxiadis [2].

The concepts of ecological-linear continental forms of settlement as a result of controlled urbanization became widespread in the 1960s and 1970s. Such settlement systems, in contrast to ecumenopolis, have a grid-like urbanized structure with a corresponding complex framework of connections. The territorial development of these systems is carried out in some cases on the basis of natural processes of self-development (the concept of landscape-ecological direction), in others taking into account synergetic methods of planning and managing their development (the concept of socio-ecological and architecturalecological direction), without taking into account administrative-territorial affiliation. Such concepts include the ideas of "new elements of settlement" (A. Baburov, A. Gutnov, I. Lezhava, S. Sadovsky, Z. Kharitonova, G. Dumengton, 1966), "kinetic system of settlement" (A. Ikonnikov, K. Pchelnikov, A. Panin, etc., 1973), "network of band elements of settlement" (M. Barkhin, 1974), and others.

The concept of "new elements of settlement" (NER) [31] is based on the idea of creating a dynamic system of group settlement in contrast to the trend of chaotic growth of large agglomerations. Such a system should consist of self-limiting integral urbanized units, "autonomous and self-sufficient in meeting the most important human needs". The concept considers two types of NER-linear, elongated along the routes, and compact, in the form of agglomeration nodes. At the continental scale, the general NER scheme creates a polygonal grid (Figure 2). The "kinetic settlement system" [32] is based on the idea of building a continuously developing grid-linear settlement structure in accordance with the needs of society, which implies the formation of a mobile self-developing dynamic ecological-urbanized grid (Figure 3). 


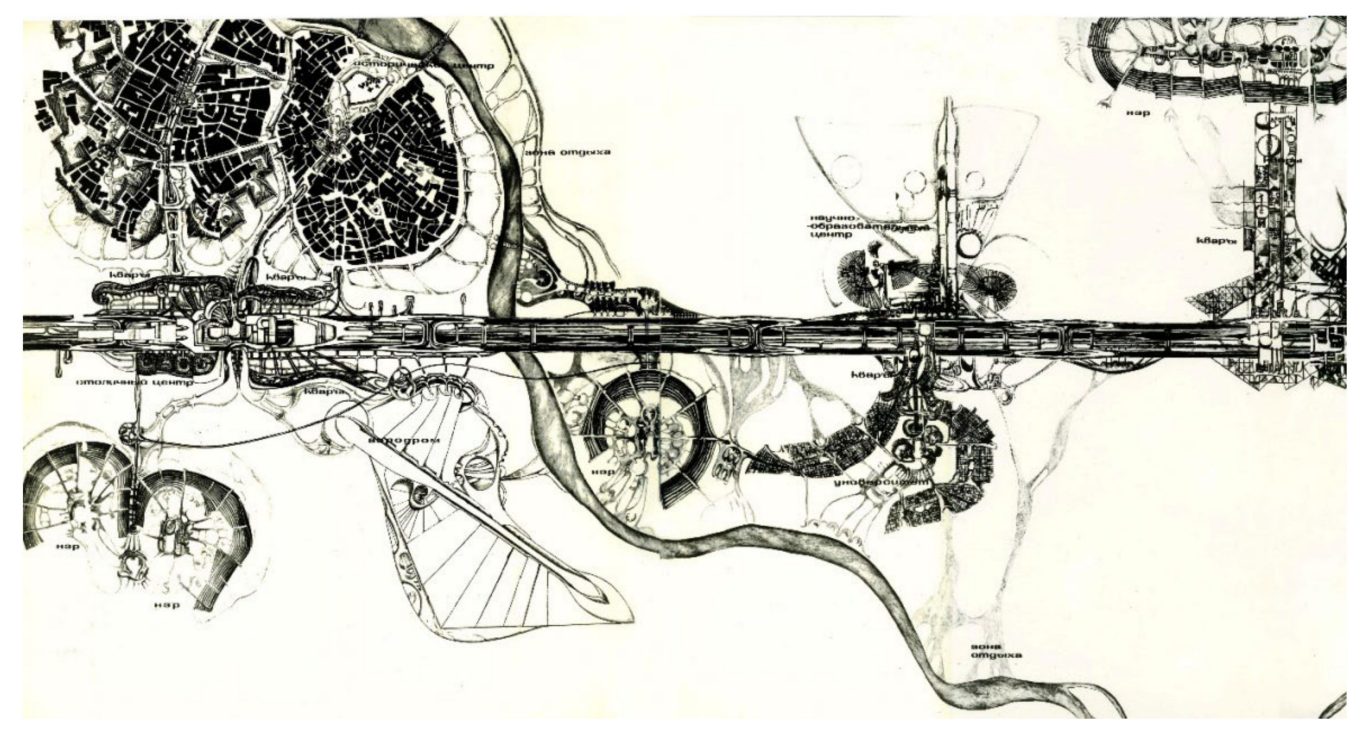

Figure 2. Fragment of the system of new settlement elements and transcontinental connections, according to A. Baburov, A. Gutnov, I. Lezhava, S. Sadovsky, Z. Kharitonova, and G. Dumengton [31].

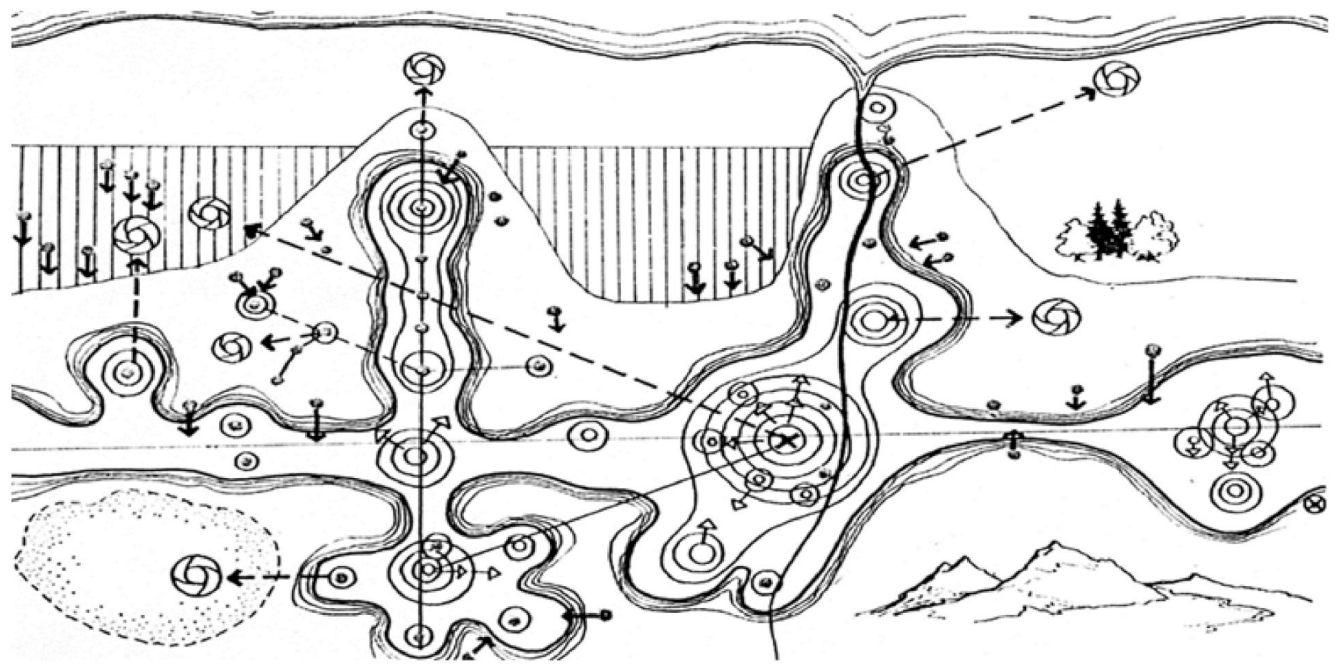

Figure 3. Fragment of the "kinetic settlement system", according to A. Ikonnikov, K. Pchelnikov, A. Panin, etc. [32].

The concept of a "network of strip elements of settlement" [33] is not a continuous urbanized network but a "living" (mobile) organization of settlement by the type of a network ribbon structure with an intermittent placement of functional zones and the preservation of natural areas. This concept was developed in the works of S. Sanok [34], based on the formation of the settlement system, taking into account the boundaries of the geocomplex and landscape, including the geological and morphological structure, the continuity of ecological relations between the components of nature. In the concept of V. Vladimirov [35], the natural framework of the settlement area or "natural fabric" is considered as the system that has the greatest ecological stability and includes, in addition to protected natural areas, other green areas with certain biological productivity.

In all these concepts, the basis of global settlement is the ecological-urbanized grid systems formed by a continuous (conditionally homogeneous) grid framework of transcontinental connections and a framework of landscape corridors. The concept of megalopolises has a somewhat different idea. 


\subsection{Concepts of Megalopolises or Megaregions}

Megalopolises or megaregions are considered by J. Gottman as extensive urbanized regions that are the result of the coalescence of a group of agglomerations as a result of changing socio-cultural and socio-economic conditions of people's lives, taking into account the rapid development of high-speed modes of transport and new types and forms of communication [3]. At the same time, the researcher sees the main factors of trends in the spatial differentiation of such forms of settlement in the interaction of "regional iconography" (national and regional identity) and physical space (geomorphology), as well as in the relationship of "circulation" or "movement", which takes into account all types and forms of spatial communication of people with infrastructural development $[4,5]$.

At the same time, the most important criteria for the processes of global urbanization are increasing forms of "circulation", such as migration (taking into account all its types from daily pendulum to interethnic and intercontinental) and "accessibility" associated with socio-territorial borders (including administrative-territorial, cultural, spiritual, and others), intercultural and interethnic integration. According to J. Gottman, spatial "accessibility" is inseparable from the concepts of "national spirit", "regional spirit", and "division of the world" [4].

An important infrastructural spatial element, according to J. Gottman, is the "intersection" ("carrefour") or a node in the network of "circulations", which helps to organize traffic and communications. The most developed form of such "crossroads" is precisely megalopolis [89].

In fact, J. Gottman denotes the closeness of each global form of settlement due to pendulum connections and the openness of these systems, taking into account integration socio-economic, migration, and other processes with corresponding transcontinental connections. With such a development of global settlement, its framework of global communications has a complex heterogeneous structure.

The first megalopolis, identified in the late 1950s of the 20th century, studied and described by J. Gottman, is a megaregion of the Atlantic coast of the United States, including a strip of 40 interconnected agglomerations of Boston, New York, Philadelphia, Baltimore, and Washington along with transport links; its area is 170 thousand square kilometers. Later, it was called "BosWash" (Figures 4 and 5a) [4].

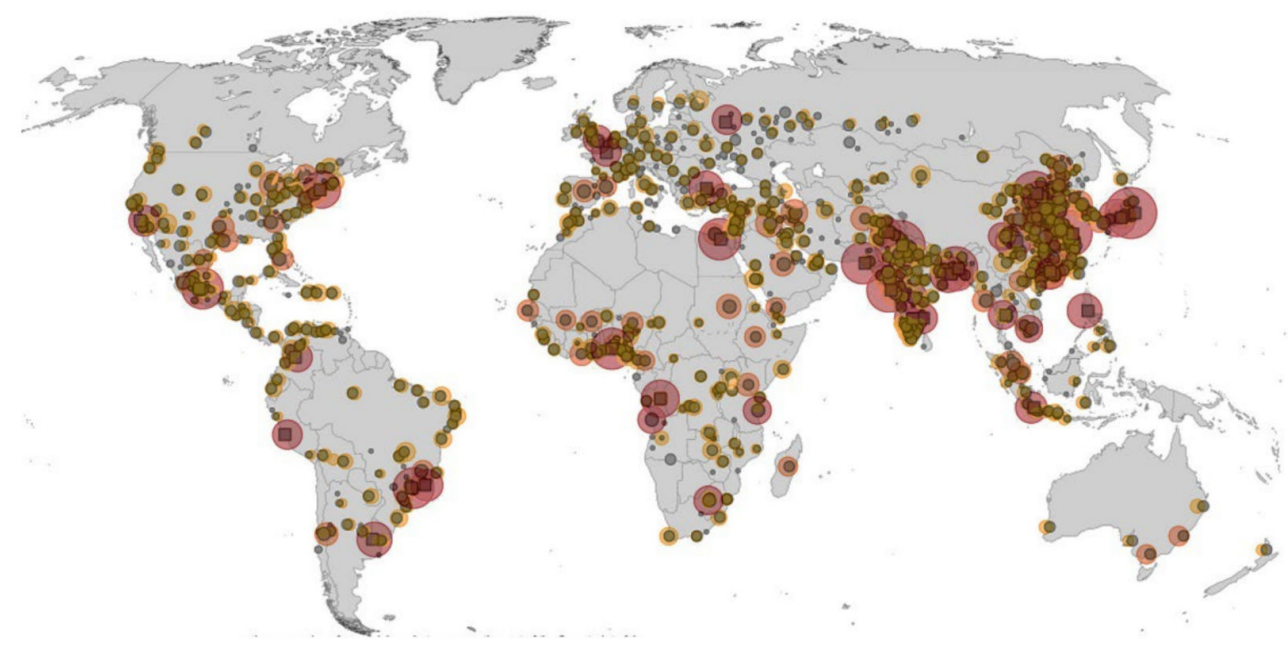

Figure 4. Urbanization and the growth of the network of megacities in the world, forecast model for 2030 (red-megacities of 10 million and more; orange-from 5 to 10 million; yellow-from 1 to 5 million), 2014. Compiled on the basis of an interactive map tracking global changes in the urban population from 1950 to 2030, UN data (source: https:/ / www.economist.com/node/21642053, accessed on 13 August 2021). 

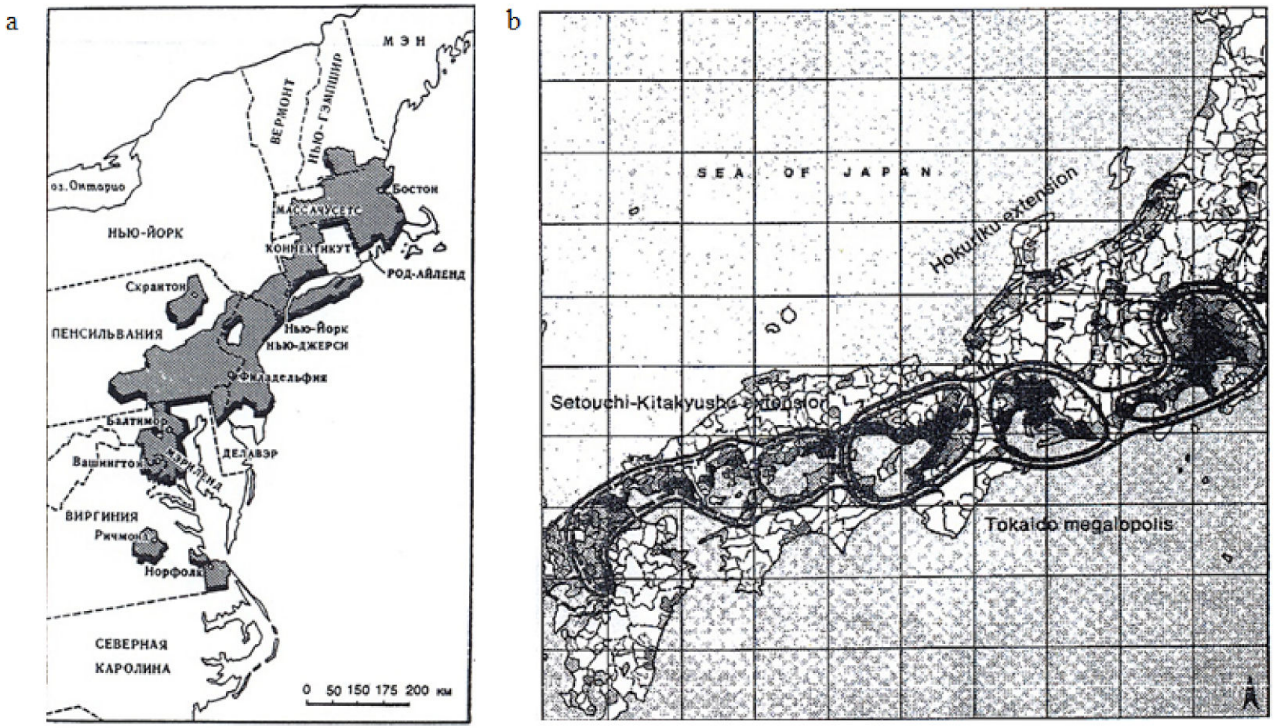

Figure 5. (a) Megalopolis "Boswash", USA, according to J. Gottman [4,5]; (b) Megalopolis “Tokaido", Japan, according to T. Doi [89-100].

The processes of urbanization in this period were influenced by changes in the socioeconomic and demographic situation of the world, associated with the Second World War and the collapse of the colonial structure. This led to the formation of supra-agglomeration settlement networks on the scale of regions and macroregions. As an example of the processes of urbanization of this period, we can consider the "Cartogram of population migration in France from 1931 to 1954", first presented in the journal Urbanism (1956, No. 49-50).

Since the 1960s, dozens of similar urbanized macroregions in the world have been studied, developing on all the populated continents of the Earth. These are "ChiPitts" (Chicago-Pittsburgh), formed by the merger of 35 agglomerations on the southern coast of the Great Lakes in the United States and including an area of 160 thousand square kilometers and a population of about 35 million people; "SanSan" in the United States, stretching from San Francisco through the chain of centers of the Great California Valley to Los Angeles and further to San Diego. This is the "Tokaido" (Figures 4 and 5b) on the Pacific coast of Japan (Tokyo-Osaka), where almost 60\% of the country's population and two-thirds of its industrial production are concentrated. The researchers also refer to megaregions as "Lon-Live" (Great Britain, the agglomeration of London, Birmingham, Manchester, and Liverpool), "Rhenish" (the conglomeration of "Randstad" in the Netherlands and the agglomeration of the Rhine-Ruhr and the Rhine-Main in Germany), the megalopolis of Northwestern Europe (on the territory of five countries, including South-East England, Randstad, the Rhine-Ruhr, the Belgian-French districts of Antwerp and Brussels-Dill, and the Paris Agglomeration), and the South China "Pearl River Delta" (including the Shenzhen Free Economic Zone, the Hong Kong agglomeration, Zhuhai, and Guangzhou). In Brazil, it is a cluster of agglomerations of Sao Paulo-Rio de Janeiro-Belo Horizonte (Figures 4 and $5 a, b)$.

In 1989, the French scientist Roger Brunet introduced the term "Blue Banana" or "Boom Banana" [90], which characterizes the territory of Western Europe with exceptional economic significance. This macro-region of unified development covers the regions of Great Britain, Belgium, the Netherlands, Luxembourg, Germany, France, Switzerland, and Italy. Later in 1995, the European Commission presented the concept of the "Golden Banana" as a territory of integrated development in the east along the Mediterranean coast, covering the regions of Italy, France, Monaco, Andorra, and Spain. Recently, the territory of joint development of Eastern Europe- the "Green Banana" - has been actively discussed; 
this macroregion includes the regions of Poland, the Czech Republic, Austria, Slovakia, Hungary, Slovenia, Croatia, and Italy.

The concept of a megalopolis or megaregion has become widespread in modern statistical and scientific works of economic geographers and representatives of ecistics. At the same time, today, there are a significant number of approaches to determining the boundaries and composition of such supra-agglomeration spatial settlement systems. However, it is significant that there is no comprehensive work on the study of the general system of megalopolises of the world and their modeling, including in terms of transportterritorial relationships and interdependencies.

\subsection{Concepts of a Global or World City}

American researcher Lewis Mumford speaks critically about megalopolises, considering them as a crisis stage in the development of cities and their agglomerations [91,92]. A similar point of view, continuing the traditions of Patrick Geddes [93,94] and Lewis Mumford, is expressed by the American sociologist and economist Saskia Sassen in 1991 and puts forward an alternative concept of "the global city" or the "world city" [39,40], or "alpha city" as applied to London, New York, Tokyo, and other megacities of the world as global centers of socio-economic growth and management of the development of macro-regions, global communications and integrations, and centers of absorption and distribution, including urban resources.

This concept, based primarily on a socio-economic approach, does not consider the formation of "global cities" from the perspective of urban planning and does not substantiate the structure of the transcontinental communications framework as a basic element of the development of the global settlement. In fact, the direct dependence of transcontinental corridors as links of "world cities" is not described in the concept under consideration. At the same time, the infrastructure framework should integrate economic macro-regions and their centers with each other [95]. It should have a complex (individual) structure of ties based on a large number of political, socio-economic, socio-cultural, and other forms of integration and sovereignty.

A group of researchers at the Loughborough University think tank for the study of Globalization and World Cities (GaWC) in 1999 proposed the structure of cities of the "Alpha", "Beta", and "Gamma" classes. In the future, this structure began to include the categories "Alpha++", "Alpha+", and others with a minus and plus coefficient. The list of leaders is headed by London, New York, Hong Kong, Beijing, Singapore, Shanghai, Sydney, Paris, Dubai, and Tokyo (Figure 6).

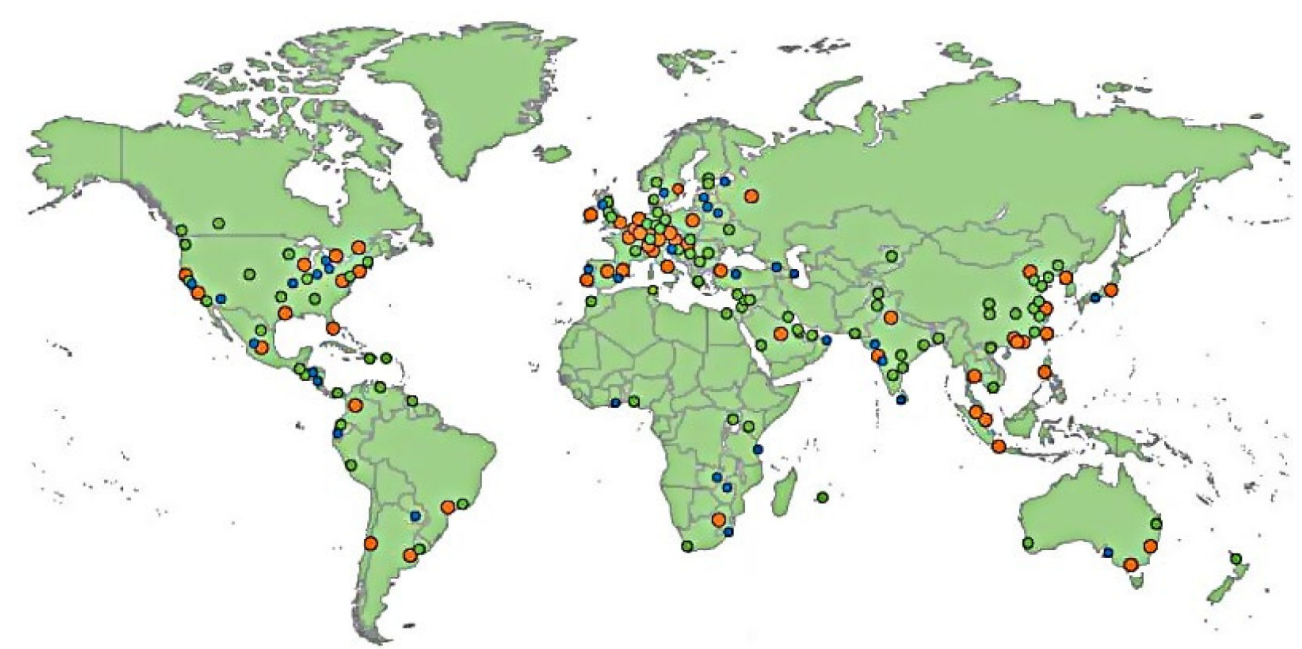

Figure 6. GaWC Global Cities Scheme (orange—alpha cities; green—beta cities; blue-gamma cities) [60]. 
At the same time, it should be noted the heterogeneity of the typologization of "global cities" in various research and statistical works from the standpoint of their population size or other urban planning, socio-economic, and other evaluation criteria. Thus, the index of the level of globalization of world cities by the international consulting company Kearney measures the level of integration of leading cities into the global space and is based on five criteria: the level of business activity, human capital, information exchange, cultural level, and political weight [96]. According to S. Sassen, the main criteria are four key groups of high-tech activities in the service sector: "financial and business services", "power and influence" or "management and control", "creative activities", and "tourism" [39,40].

The works of researchers such as P. Taylor and the GaWC group are devoted to the development of the concept of a "global city". However, these works do not take into account the criteria of infrastructural connectivity and communication integrality of "world cities".

In turn, today, we publish studies that are alternative to the above-mentioned approach to "global and world cities" as centers of the world economy, government, and culture. Such theories include the work of, for example, geographer Jennifer Robinson with the idea of "dissimilar cosmopolitanisms" [51]. In his publication "Global and World Cities: A View from off the Map" [52], this researcher proposes to significantly change the approach to studying the processes of globalization, structuring, and systematization of a large number of different forms of urbanization and, as a consequence, the relations between different settlement systems. At the same time, urban planning analytics of globalization processes should take into account such contradictory aspects as "developmentalism", "the third world", and the states of the "West", among others. Such an economic-social and economicpolitical approach to the development of world settlement requires its own multifactorial urban planning forecasting, planning, and modeling, including a single framework of transcontinental links as a single complex urban planning system.

According to P. Hall, "world cities" should be distinguished by powerful traffic flows and communications, including road and railway systems, as well as international air and sea routes [36]. According to S. Sassen, the "global city" should be maximally integrated into the world economy, including through or as a result of interaction in global urban networks $[39,40]$. Nevertheless, research works devoted to the study of the transport connectivity of such cities of the world have not been established today.

\subsection{Strategic Programs and Projects for the Formation of a Network of Cross-Border and Transcontinental Corridors}

The framework of global settlement is now being actively formed by cross-border interstate and transcontinental connections-by road, rail, air, water, sea, and pipeline. These are corridors that provide socio-economic and socio-cultural communication between megaregions and "global cities". The presence of such infrastructure today creates priorities for the development of some macroregions and the absence of such priorities or "crossborder barriers" for others, excluding them from global communication processes.

An example is the Central Asian Regional Economic Cooperation (CAREC), which is a partnership of eleven countries (Afghanistan, Azerbaijan, the People's Republic of China (PRC), Georgia, Kazakhstan, the Kyrgyz Republic, Mongolia, Pakistan, Tajikistan, Turkmenistan, and Uzbekistan) and six international development institutions (the Asian Development Bank (ADB), the European Bank for Reconstruction and Development, the International Monetary Fund, the Islamic Development Bank, the United Nations Development Program, and the World Bank), the purpose of which is to promote regional integration through infrastructure and trade facilitation through the implementation of transcontinental Asia-Europe links (Figure 7). According to analysts N. Hildyard and X. Sol [97-101], there is "shifting the trajectory of corridors from mere transport routes to economic corridors", as a result of which CAREC is criticized for insufficient participation of a number of countries and lack of connection with national and regional strategies and plans. 


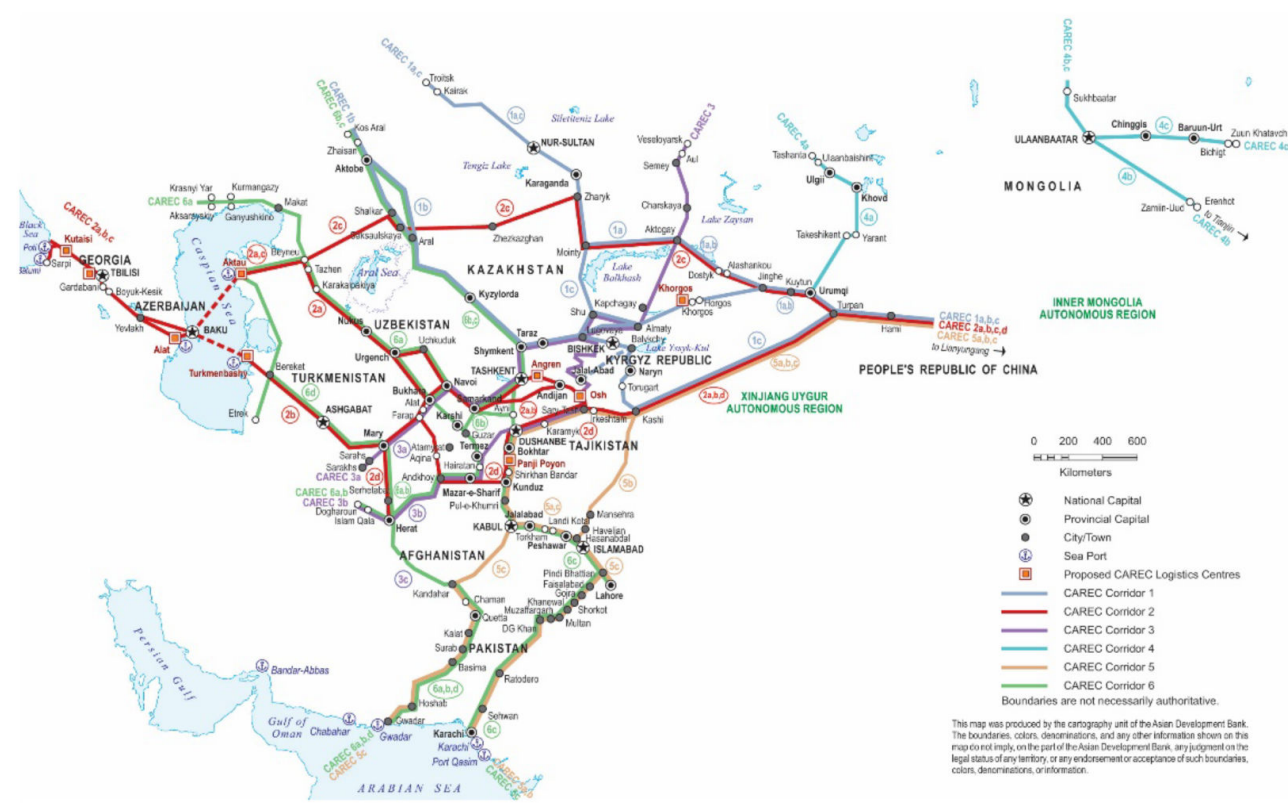

Figure 7. CAREC multimodal corridors (1. Europe-East Asia; 2. Europe-Mediterranean-East Asia; 3. Russian Federation-Middle East and South Asia; 4. Russian Federation-East Asia; 5. East Asia-Middle East and South Asia; 6. Europe, Middle East, and South Asia) [97-102].

Additionally, analytical materials of the Department of Transport and Infrastructure of the Eurasian Economic Commission, publications and reviews of financial institutions, research centers, industry organizations of the United Nations Economic Commission for Europe, the Organization for Railway Cooperation, the Eurasian Development Bank, and other organizations show significant "gaps" in transport communications and corridors of the Eurasian continent, which does not allow all participants in this transport system to use the existing communication and transit potential, and in some cases, it leads to the transport isolation of a number of states [68].

At the same time, it should be noted that over the past decade, complex works of the spatial organization of promising settlement systems and transport links have begun to take shape not only from the position of a specific country or other administrative-territorial units but within the framework of the agreement of a significant number of countries and macro-regions. Such works should include the Silk Road Economic Belt megaproject, as well as strategic urban development projects for the integrated development of the European Union, sections of cross-border territories of the People's Republic of China (PRC), Russia, and other countries.

The development of transcontinental ties between the Eurasian countries is carried out along the "West-East" latitudinal lines, including the existing and planned routes of the Northern Sea Route, the maritime transport route through the Suez Canal (Shanghai-Hong Kong-Singapore-Colombo-Cairo-Lisbon-Duisburg), the Trans-Caspian transport route, the international corridor "Western Europe-Western China" and the Trans-Siberian Railway through Russia, the route "North-South", as well as within the framework of the New Silk Road Economic Belt (Eurasian Land Bridge) project, uniting the EU macro-regions with China and the Asia-Pacific region. At the same time, the main volume of exported goods, for example, of the Eurasian Economic Union, is produced by sea and river ( $58.5 \%$ of the physical volume), pipeline (21.5\%), railway (17.7\%) transport; and imports by sea and river $(36.4 \%)$, rail $(34.3 \%)$ and road $(27.1 \%)$ transport (Figure 8$)$. 


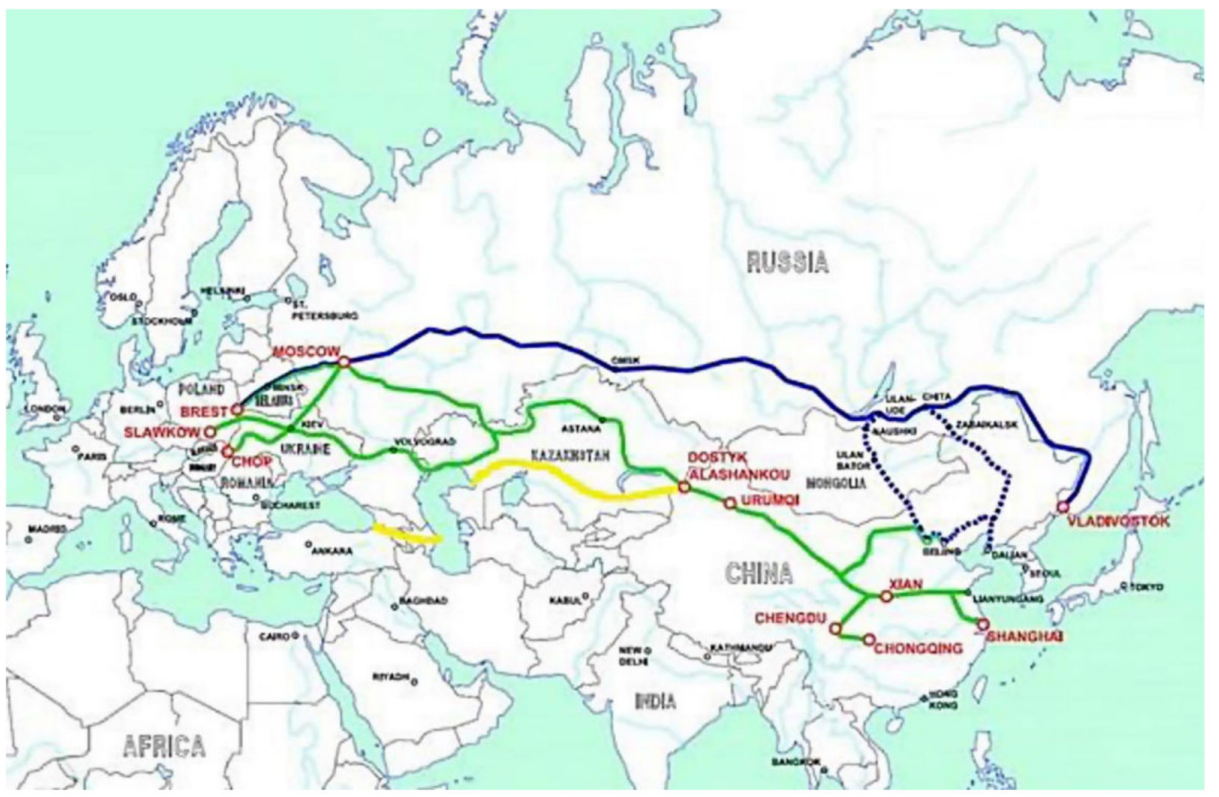

Figure 8. The main Eurasian routes of transit cargo flows in the framework of the implementation of the megaproject Economic Belt of the Silk Road (blue-main existing Trans-Siberian railways route; green and yellow-new east-west rail corridor routes via Kazakhstan) [68].

According to analysts, the most significant sections of the transport system of Eurasia are considered: pan-European transport corridors (Cretan) in Central and Eastern Europe; transport routes of the Eurasian Economic Community; railway transport corridors of the Organization for Railway Cooperation; links of the Central Asian Regional Economic Cooperation Program; routes of the Euro-Asian Transport Conference; corridors of the Shanghai Cooperation Organization; communications of the Inland Transport Committee of the United Nations Economic Commission for Europe; corridors of the countries of the Commonwealth of Independent States (Figure 9) [68,69].

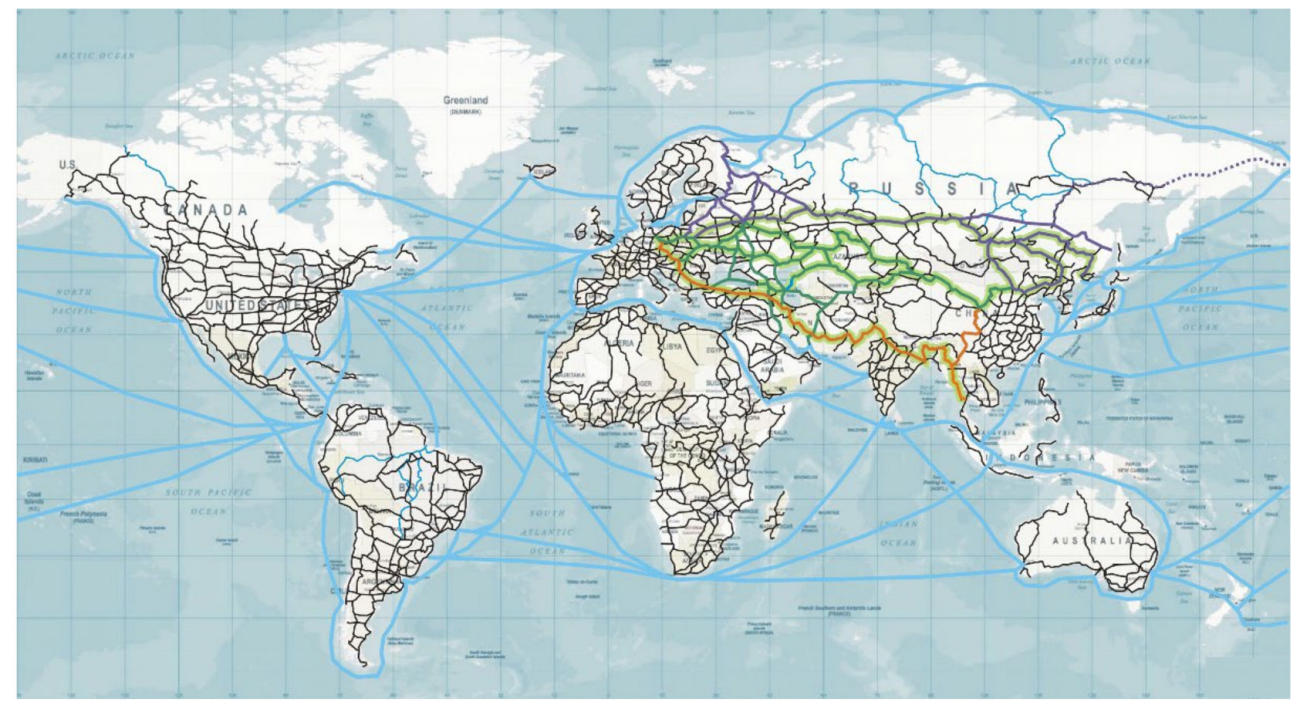

Figure 9. The model of Eurasian transcontinental links in the world transport system (black—existing transport links, on the territory of Eurasia-not involved in transcontinental relations; blue-the main river transport corridors; light blue — the main sea and transoceanic routes; purple- the main existing Trans-Siberian railways route and formed diagonal links; green-new east-west rail corridor routes via Kazakhstan, as well as formed diagonal and meridional links between the main latitudinal corridors; orange-the southern corridor being formed) [68-75]. 
Cartographic modeling shows that the formed framework of transcontinental transport connections of the Eurasian continent does not fit into the concepts of the global settlement, such as the concepts of ecumenopolis (Figure 10), network forms of settlement, megalopolis (Figure 11), and "global city" (Figure 12). Such latitudinal connections pass through the territories of macro-regions and countries of different socio-economic statuses and levels of urbanization (including the degree of population). Graphical analysis shows that one of the main criteria for tracing new latitudinal corridors is the territorial and time limit between the final participants of transport or engineering pipeline communications and administrative-territorial relations. This leads to a situation where socially and economically important macroregions and "cities of the world", many countries, and large territories have the role of transit without organized logistics and distribution hubs. At the same time, such latitudinal connections are considered self-sufficient, that is, without being included in the infrastructure frameworks of macro-regions and countries participating in transcontinental infrastructure flows.

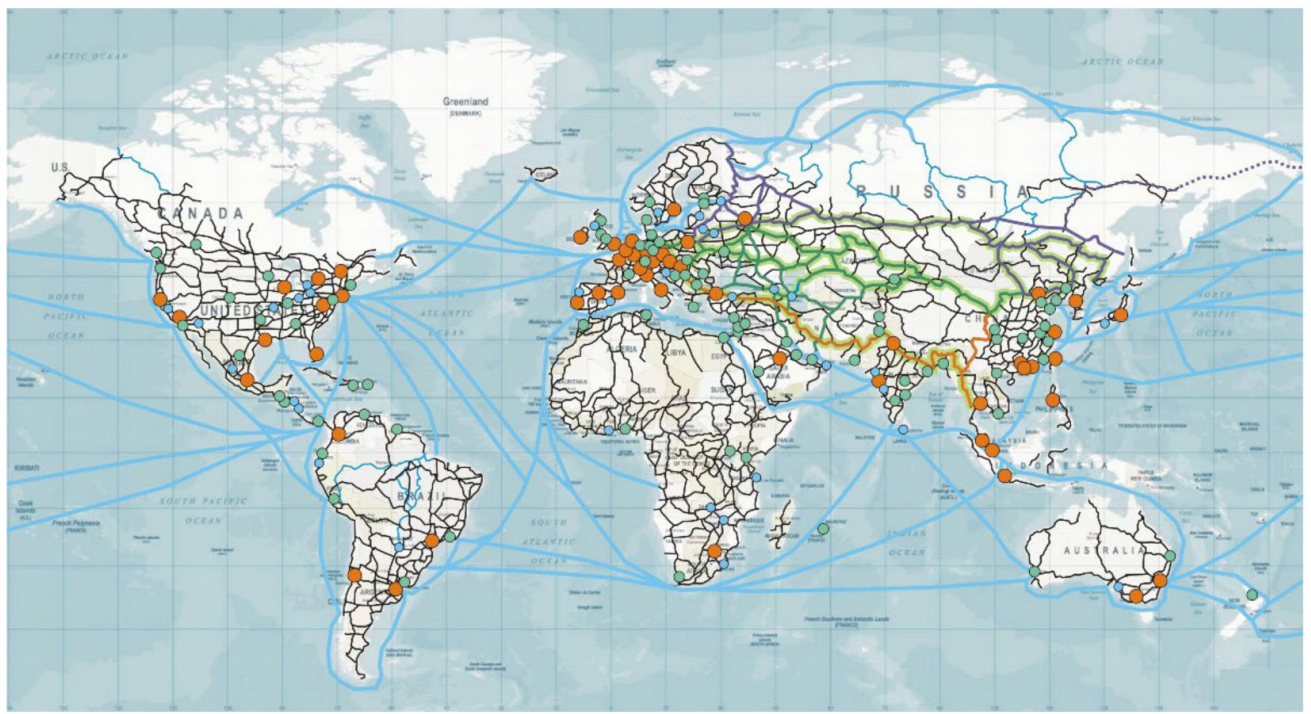

Figure 10. A model of the relationship of Eurasian transcontinental links in the global transport system and the structure of world cities according to GaWC (orange—alpha cities; green — beta cities; blue-gamma cities).

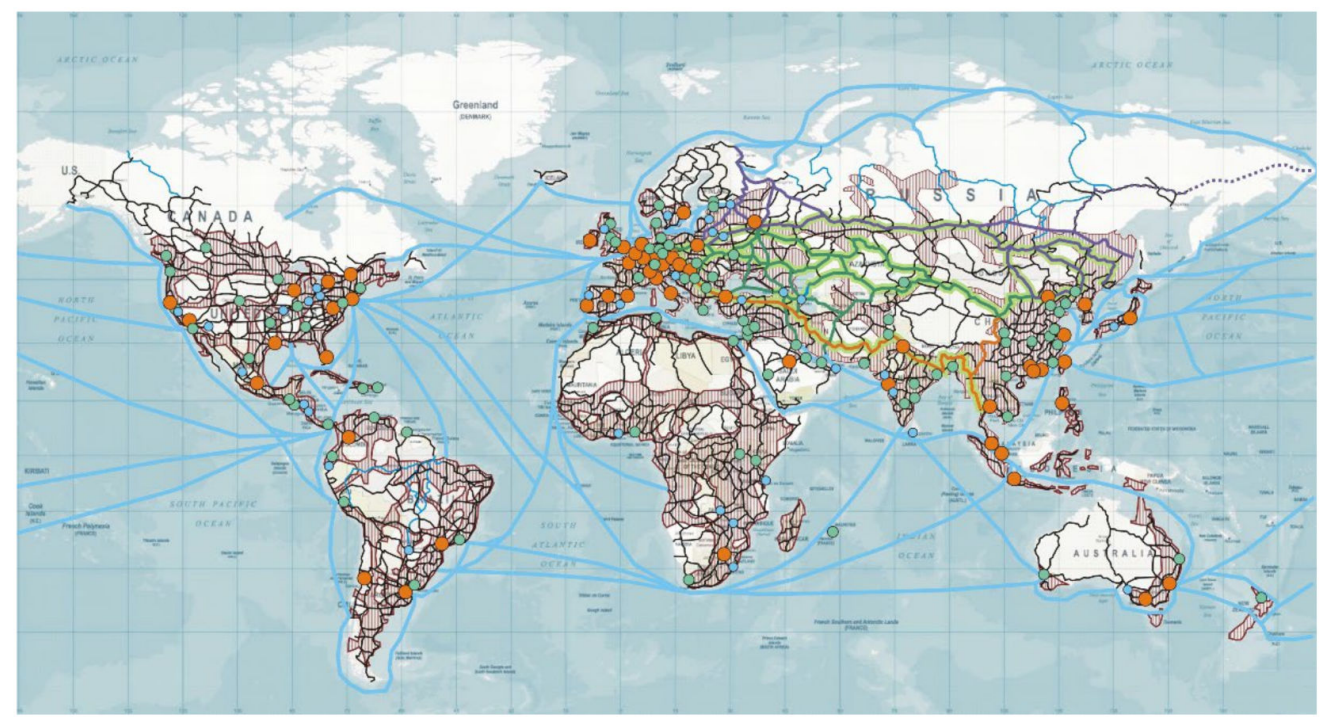

Figure 11. A model of the relationship of Eurasian transcontinental links in the world transport system, world cities according to GaWC and the ecumenopolis system according to K. Doxiadis. 


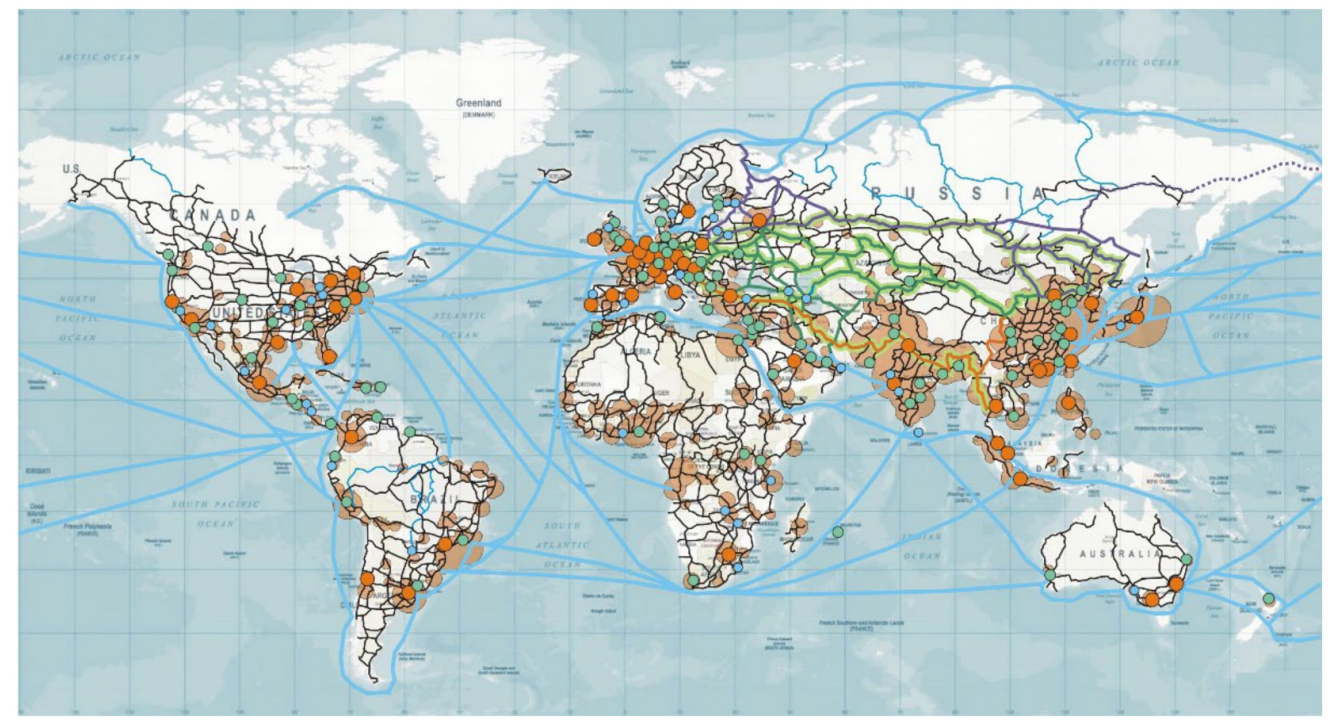

Figure 12. A model of the relationship of Eurasian transcontinental links in the world transport system, world cities according to GaWC and the system of megaregions (built on the basis of a forecast model according to UN data).

\section{Discussion}

\subsection{Features and Problems of the Formation of a Unified Global Settlement Framework}

Co-existing and evolving at the same time, all these theories of the organization of global settlement-ecumenopolis, megalopolis, and the "global city" - today have approbation research and statistical base that characterizes the passage of these processes of urbanization in the world.

At the same time, any of the presented concepts of urbanization of settlement implies the formation of a single and integral framework of global communication links, integrated and interconnected with the structure of the global settlement. However, the cross-border and transcontinental corridors formed on the basis of international strategic programs and projects today are not decisive in the organization of the global settlement system and in the processes of global urbanization and do not form a unified framework of the world transport infrastructure. In fact, these programs and projects are fragmented and disconnected from analytical data and forecasts of the development of a unified system of transnational megalopolises (macroregions) and rapidly developing "global cities". This situation is exacerbated by political and administrative-legal restrictions that do not take into account all the stakeholders of these processes, the profile or departmental features of these strategic documents of a transport-logistics and transport-economic nature, and the lack of unified institutions and planning centers.

In this connection, from the standpoint of urban planning theory and "Systems Theory", taking into account the above-mentioned concepts of the development of global settlement, such a situation requires a revision of the existing and planned system of global latitudinal, meridional, and diagonal connections and communication and distribution nodes-centers between them with the involvement of all participants in these processes in order to form a single international infrastructure framework.

At the same time, megalopolises (macroregions) and "global cities", as well as an infrastructural transcontinental integration framework, should form a unified system of the global settlement while acting as its urban planning elements. In addition, the formation of such a system should take into account both socio-economic and administrative-legal, as well as unique natural and ecological (including climatic), natural and geographical (including geological and morphological), and historical and cultural (also interethnic and transmittal) aspects of the processes of global urbanization. According to V. Vernadsky's theory of "movement to the noosphere", the need to form a unified scientific base for 
planning world settlement and the framework of its communications is justified by the need to move from the "coevolutionary" stage of world development to the "homeostatic" one.

These provisions determine the relevance of the further study of the scientific foundations of urban planning analysis, forecasting, planning, and management of the development of transcontinental links and global settlement within the framework of urban planning theory and "Systems Theory".

\subsection{Methodical Aspects of Conflict Resolution Related to the Processes of Urbanization and the Development of Global Communications}

Today, two main simultaneously developing scenarios for the development of the world of socio-economic and environmental character from the perspective of globalization are being discussed. The first is characterized by a regime with an aggravation with an increase in the intensity of the process of population growth and its distribution in space. In such a scenario, it is possible to strengthen the struggle for resources and increase the dangers of natural, social, and man-made nature, the development of terrorism, and the development of military conflicts. This scenario determines the need for urban planning to improve the social and environmental security of states and macro-regions of the world. The second scenario is associated with a change in the law of the growth of the world's population. This is an opportunity for broad international cooperation in the interests of present and future generations and the development of the information environment, culture, and new technologies, increasing the role of exchange processes and the corresponding infrastructure in society as mechanisms for stabilizing population growth and eliminating threats.

Both of these scenarios determine priorities in the intensive formation of the scientific foundations of the theory of spatial sustainable development of a single system of macro-regional and global forms of settlement and its framework of connections. The fundamentals of the analysis and planning of such settlement development should be the "end-to-end" modeling of global, regional, and local sustainable urban integration, incluing communication and processes, as well as problems, crises, and threats.

As urban planning methods for resolving the existing conflicts of urbanization processes between the elements of world settlement as socio-economic macro-regions, "world cities", and transcontinental connections, as well as ensuring their sustainable interaction, methods of organizing urban planning systems based on the territories of partnerships and the formation of settlement based on the development of the uniqueness of territories, presented in the works of Russian researchers V. Spiridonov and V. Kolyasnikov, can be applied $[97,98]$.

The first method is based on the identification and planning of interstate, macroregional, and local administrative-legal, socio-economic, environmental (natural-climatic), natural-geographical (including geological-morphological), historical-cultural (also interethnic and transmittal), and other relationships and areas of joint interests. Four groups of priority territories of joint interests and partnership relations can be identified: interstate, state, inter-macroregional, and macroregional significance.

The second method is related to the identification and development of the settlement system, taking into account the unique features of macroregions, their centers, natural and ecological frameworks, "world cities", and transcontinental connections as competitive advantages. At the same time, it is necessary to consider the unique features of historicalcultural, ecological, natural-landscape, functional-economic, communication, innovative, and aesthetic nature as the potential for the development of territories and the formation of appropriate settlement frameworks based on these features. At the same time, the priority tasks of spatial planning of sustainable settlement development are the tasks of urban planning to ensure the infrastructural, ecological, socio-economic, functionaleconomic, historical-cultural, and aesthetic well-being of the territory; synthesis of urban planning and engineering solutions; balance of economic and environmental processes; 
coordinated development of territories of various hierarchical levels; and rational use of natural resources in the interests of present and future generations.

The above methods are presented in detail on the example of a specific Ural macroregion in the work Modern Theory and Practice of Urban Planning: Settlement Spatial Development (V. Kolyasnikov, V. Spiridonov, 2016) [97].

\subsection{Methodological Aspects of Conflict Resolution Related to the Processes of Urbanization and the Development of Global Communications}

The main urban planning tasks of streamlining the processes of globalization forms of settlement and world urbanization, taking into account the relevant integration communication links, are (1) creating relationships based on compromises between the natural and ecological environment (including geological and morphological and general climatic), the anthropogenic environment and Man (the population of the Earth with its various forms of community and communication);(2) finding compromises for the joint development of macroregions, "world cities", and transcontinental connections; (3) the balance of urban planning principles-antonyms as the principles of forecasting, planning. and managing the development of such complex processes as the world urban, natural-ecological, climatic, and infrastructure-communication processes.

The proposed "principles-compromises" are aimed at resolving possible conflicts and threats, ensuring the necessary relationships between socio-economic macro-regions, "world cities", and transcontinental structures, as well as ensuring the interaction and interdependence of the natural-ecological, anthropogenic environment, and Man [99-102]. They can be considered as the following pairs of principles-antonyms: (1) balance of linearity and discontinuity of functional urbanized and natural-ecological zones and structures of the global settlement system; (2) the balance of dynamism and static nature of the main structures (administrative-legal, socio-economic, ecological, natural-geographical, sociocultural, and historical-cultural) and the elements of the urban planning system; that is, respectively, its anthropogenic and natural elements, the role of Man in this relationship; (3) the balance of openness and closeness of subsystems, taking into account their sociability and incompatibility; (4) the balance of openness and isolation of the elements of naturalecological, socio-urban, and socio-cultural subsystems of global settlement; (5) the balance of communicative integrality and alienation; (6) balance accessibility and autonomy or barrier-free; (7) the balance of attraction and rejection or delaying socio-economic and urabanizational activities.

The synergy of these seven urban planning principles-antonyms offers a research search for mechanisms for forecasting, planning. and managing the development of complex global urban processes in order to ensure a sustainable balance in the interests of present and future generations.

\section{Conclusions}

1. A critical analysis of the main author's concepts of the development of world settlement systems, some alternative concepts of globalization, important from the perspective of urban planning issues, significant modern statistical analytical data on the issue under consideration, and existing strategic programs and projects for the development of a network of transcontinental transport links (in open access), including graphic materials presented in these data, showed that today there is a modernization of scientific and strategic approaches to planning a global settlement system, what is expressed in the active development of concepts, international programs and plans for the spatial organization of the largest settlement systems, the global economy, and cross-border and transcontinental transport links.

Despite the significance of such a movement, these changes are not systemic in nature. This is reflected in the absence of a generally accepted comprehensive research (scientific-statistical, scientific-analytical, scientific-forecast) and project base for the study and planning of transcontinental connections and global settlement, as well as in the ab- 
sence of comprehensive works on the study of the globalization of settlement systems, taking into account the impact of cross-border and transcontinental connections on global urban and interethnic integration and communication processes.

2. Graphoanalytical modeling of the interrelation of Eurasian transcontinental links in the world transport system, the structure of world cities, forecast models of ecumenopolis, megalopolis systems (megaregions), as well as theoretical conclusions of critical analysis of research, conceptual, statistical data, and other open access sources, have shown the need for the formation of international research and design institutes for the study, forecasting, planning, and management of the development of transcontinental links and global settlement.

Urban planning, at the same time, consolidating issues of infrastructural, functionaleconomic, natural-ecological, and climatic settlement and socio-cultural nature can become an interdisciplinary scientific and practical basis for the progressive spatial development of all countries and continents of the world and the corresponding framework of settlement.

3. The practical significance of the presented results of the work is that the proposed methodological aspects, including the synergy of seven urban planning principlesantonyms, as well as two methods of organizing urban planning systems, can be used in the formation of scientific and methodological foundations of urban planning analysis, forecasting, planning, and modeling of the development of complex global urban processes in order to ensure a sustainable balance in the interests of present and future generations. The main provisions of the work can be included in bachelor's and master's degree programs in the specialty of urban planning.

These conclusions are not the result of the application or experimentation of an innovative model in a case study but are the theoretical conclusions of critical analysis.

The scientific novelty of this work lies in the fact that for the first time from the perspective of modern urban planning, the need to develop generally accepted methodological and methodological provisions for the study and planning of various forms of world settlement and their interrelations (including in relation to a single global transport framework) is justified as a Single System; for the first time, from the perspective of modern urban planning, some problems of scientific-statistical, scientific-analytical, and scientific-predictive nature of studying the interdependence of transcontinental ties and global settlement are outlined; for the first time, from the perspective of modern urban planning, methodological aspects of the study and planning of globalization processes as a relationship between the formation and development of various forms of world settlement and a single global transport framework are proposed, including seven urban planning principles-antonyms, as well as two methods of resolving the existing conflicts of urbanization processes between elements of world settlement as socio-economic macro-regions, "world cities", and transcontinental links - the organization of urban-building systems based on the territories of partnerships and the formation of settlement based on the development of the uniqueness of the territories.

The presented work can become a methodological basis for further large-scale scientific research in the field of studying the processes of globalization from the perspective of modern urban planning. It helps to analyze (statistically, strategically, cartographically, etc.) the formation and development of various forms of world settlement, their interrelations and interdependencies, a single global transport framework. The obtained research results can contribute to the development and consolidation of the provisions of the theory of urban planning in relation to tasks of global importance.

Author Contributions: Conceptualization, V.S., S.S. and S.A.; writing-original draft preparation, V.S., S.S. and S.A.; writing—review and editing, V.S., S.S. and S.A.; methodology, V.S., S.S. and S.A.; project administration, V.S., S.S. and S.A. All authors have read and agreed to the published version of the manuscript.

Funding: This research received no external funding.

Institutional Review Board Statement: Not applicable. 
Informed Consent Statement: Not applicable.

Data Availability Statement: Not applicable.

Conflicts of Interest: The authors declare no conflict of interest.

\section{References}

1. Doxiadis, C.A. Ekistics: An Introduction to the Science of Human Settlements; Oxford University Press: New York, NY, USA, 1968.

2. Doxiadis, C.A.; Papaioannou, J.G. Ecumenopolis: The Inevitable City of the Future; Athens Center of Ekistics: Athens, Greece, 1974.

3. Gottmann, J. L'Amerique; Hachette: Paris, France, 1954.

4. Gottmann, J. Megalopolis. In the Urbanized Northeastern Seaboard of the United States; The Twentieth Century Fund: New York, NY, USA, 1961.

5. Gottmann, J. Megalopolitan systems around the world. Ekistics 1976, 243, 109-113.

6. Papaioannou, J.G. Population Projections for Ecumenopolis; Athens Center of Ekistics: Athens, Greece, 1970.

7. Berry, B.J.L.; Horton, F. Geographic Perspectives on Urban Systems; Prentice-Hall: Hoboken, NJ, USA, $1970 ;$ ISBN 9780133513127.

8. Hagerstrand, T. Innovation Diffusion as a Spatial Process; University of Chicago Press: Chicago, IL, USA, 1968. [CrossRef]

9. Song, J. Studies of city-regions-survey on the regional economic foundation of urban development. Acta Geogr. Sin. 1980, 4, 277-287.

10. Zhou, Y. Definition of urban place and statistical standards of urban population in China: Problem and solution. Asian Geogr. 1988, 7, 12-18.

11. McGee, T.G. New Regions of Emerging Rural-Urban Mix in Asia: Implications for National and Regional Policy; Seminar on Emerging UrbanRural Linkage: Bangkok, Thailand, 1989.

12. Ginsburg, N.S.; Koppel, B.; McGee, T.G. The Extended Metropolis: Settlement Transition Is Asia; University of Hawaii Press: Honolulu, HI, USA, 1991. [CrossRef]

13. Lynch, K. Good City Form; University of Harvard Press: Boston, MA, USA, 1980.

14. Borchert, J.R. Megalopolis: Washington D.C. to Boston (Touring North America); Rutgers University Press: New Brunswick, NJ, USA, 1992

15. Putnam, S.H. An Empirical Model of Regional Growth: With an Application to the Northeast Megalopolis; Regional Science Institute: Philadelphia, PA, USA, 1975.

16. Wade, M. The International Megalopolis; University of Toronto Press: Toronto, ON, Canada, 1969.

17. Weller, R.H. An Empirical Examination of Megalopolitan Structure. Demography 1967, 4, 734-743. [CrossRef]

18. Short, J.R. Liquid City: Megalopolis and the Contemporary Northeast; RFF Press (Resources for the Future): Washington, DC, USA; Johns Hopkins University Press: Baltimore, MD, USA, 2010. [CrossRef]

19. Haynes, K.E. Infrastructure: The Glue of Megacities. In Megacities: Exploring a Sustainable Future; Buijs, S., Tan, W., Tumas, D., Eds.; OIO Publishers: Rotterdam, MD, USA, 2006.

20. Fang, C.; Yu, D. Urban agglomeration: An evolving concept of an emerging phenomenon. Landsc. Urban Plan. 2017, 162, 126-136. [CrossRef]

21. Kanemoto, Y.; Tokuoka, K. Proposal for the standards of metropolitan areas of Japan. J. Appl. Reg. Sci. 2002, 7, 1-15.

22. Scott, A.J. Global City-Region: Trends, Theory, Policy; Oxford University Press: Oxford, UK, 2001.

23. Zhang, W. Concept, characteristics and planning exploration for metropolitan areas. Urban Plan. 2003, 23, 47-49.

24. Loibl, W.; Etminan, G.; Gebetsroither-Geringer, E.; Neumann, H.-M. Characteristics of Urban Agglomerations in Different Continents: History, Patterns, Dynamics, Drivers and Trends. Urban Agglom. 2018, 29-63. [CrossRef]

25. Honermann, H.; Witter, R.; Scherrer, I. Gestaltung von Mobilität in Agglomerationen; Initialstudie-Schnittstellen im ÜBergangsbereich Nationaler, Regionaler und Lokaler Netze in Agglomerationen, Bundesamt für Raumentwicklung (ARE): Ittigen, Switzerland, 2020.

26. Morley, D.; Rao, A.; Ross, C.; Peña, J. Multi-MPO Planning: Prospects and Practices; American Planning Association: Chicago, IL, USA, 2020.

27. Moisseev, I.M. Destructurization Phantoms within a System of Urban Development Planning. Archit. Mod. Inf. Technol. 2019, 4, 224-234. [CrossRef]

28. Ziyatdinov, T.Z. Megaregions: Causes, scope, characteristics and challenges of development. Bull. BSTU Named After V.G. Shukhov 2021, 8, 35-44. [CrossRef]

29. Baigent, E. From the Omens of Babylon: Astrology and Ancient Mesopotamia; Arkana: London, UK, 1994; ISBN 0-14-019480-0.

30. Morrill, R. Classic Map Revisited: The Growth of Megalopolis. Prof. Geogr. 2006, 58, 155-160. [CrossRef]

31. Gutnov, A.; Lezhava, I.; Baburov, A.; Dumenton, G.; Sadovsky, S.; Kharitonova, Z. New Element of Settlement: On the Way to a New City; Stroyizdat: Moscow, Russia, 1966.

32. Ikonnikov, A.; Pchelnikov, K. Kinetic Settlement System; Stroyizdat: Moscow, Russia, 1973.

33. Barkhin, M. City 1945-1970: Practice, Projects, Theory; Stroyizdat: Moscow, Russia, 1974.

34. Spiridonov, V. Development of the Concepts of Territorial Settlement Planning; Ural State Academy of Architecture and Art: Yekaterinburg, Russia, 2007. 
35. Vladimirov, V.; Mikulina, E.; Yargina, Z. City and Landscape (Problems, Constructive Tasks and Solutions); Thought: Moscow, Russia, 1986.

36. Hall, P. The World Cities; McGraw-Hill: London, UK, 1966.

37. Friedman, J.R. The world city hypothesis: Development and change. Urban Stud. 1986, 23, 59-137. [CrossRef]

38. Friedmann, J.R.; Wolff, G. World City Formation: An Agenda for Research and Action. Int. J. Urban Reg. Res. 1982, 3, 309-344. [CrossRef]

39. Sassen, S. The Global City: New York, London, Tokyo; Princeton University Press: Princeton, NJ, USA, 1991; ISBN 0-691-07063-6.

40. Sassen, S. Globalization and its discontents. Essays on the New Mobility of People and Money; New Press: New York, NY, USA, 1998; ISBN 1-56584-518-8.

41. Taylor, P.J. World City Network: A Global Urban Analysis; Routledge: London, UK, 2004; ISBN 9781138843578.

42. Taylor, P.J.; Aranya, R. A Global 'Urban Roller Coaster'? Connectivity Changes in the World City Network, 2000-2004; GAWC Research Bulletin; Taylor \& Francis: Cambridge, UK, 2006. [CrossRef]

43. Taylor, P.J.; Lang, R.E.U.S. Cities in the 'World City Network'; Taylor \& Francis: Washington, DC, USA, 2005.

44. Taylor, P.J.; Derudder, B.; Witlox, F. Comparing Airline Passenger Destinations with Global Service Connectivities: A Worldwide Empirical Study of 214 Cities. Urban Geogr. 2007, 28, 232-248. [CrossRef]

45. Beaverstock, J.V.; Smith, R.G.; Taylor, P.J. World City Network: A New Metageography? Ann. Assoc. Am. Geogr. 2000, 90, 123-134. [CrossRef]

46. Beaverstock, J.V.; Smith, R.; Taylor, P. A Roster of World Cities. Cities 1999, 16, 445-458. [CrossRef]

47. Taylor, P.J. Specification of the World City Network. Geogr. Anal. 2001, 33, 181-194. [CrossRef]

48. Taylor, P.J.; Catalano, G.; Walker, D.R.F. Measurement of the World City Network. Urban Stud. 2002, 39, 2367-2376. [CrossRef]

49. Bronger, D. Metropolen, Megastadte, Global Cities; Die Verstadterung der Erde: Darmstadt, Germany, 2004; ISBN 978-3-534-26403-2.

50. Pacione, M. Urban Geography: A Global Perspective; Routledge: London, UK, 2001; ISBN 9780415462020.

51. Robinson, J. City futures: New territories for development studies. In Development and Displacement; Robinson, J., Ed.; Oxford University Press: Oxford, UK, 2002; pp. 141-204.

52. Robinson, J. Global and World Cities: A View from Off the Map. Int. J. Urban Reg. Res. 2002, 26, 531-554. [CrossRef]

53. Marcuse, P.; Kempen, R.V. Globalizing Cities: A New Spatial Order? Blackwell Publishing Ltd.: Hoboken, NJ, USA, 2000. [CrossRef]

54. Isin, E.F. Who is the new citizen? Toward a genealogy. Citizsh. Stud. 1997, 1, 115-132. [CrossRef]

55. Lo, F.; Yeung, Y. Globalization and the World of Large Cities; United Nations University Press: Tokyo, Japan, 1998 ; ISBN 9789280809992.

56. Short, J.R.; Kim, Y.-H. Globalization and the City; Longman: London, UK, 1998. [CrossRef]

57. Castells, M.; Cardoso, G. (Eds.) The Network Society: From Knowledge to Policy; Johns Hopkins Center for Transatlantic Relations: Washington, DC, USA, 2005; ISBN 0976643456.

58. Castells, M. Materials for an exploratory theory of the network society. Br. J. Sociol. 2000, 51, 5-24. [CrossRef]

59. Smith, R.G. Beyond the global-city concept and the myth of 'command and control'. Int. J. Urban Reg. Res. 2014, 38, 98-115. [CrossRef]

60. Taylor, P.J. The World According to GaWC 2000. World City Network Formation in a Space of Flows, the Globalization and World Cities (GaWC) Research Group and Network. 2020. Available online: https://www.lboro.ac.uk/gawc/world2000.html (accessed on 30 May 2021).

61. Nasr, A.; Lohmeyer, R.; Al Habr, A.; Buckstaff, B. Global Cities: Divergent prospects and New Imperatives in the Global Recovery. 2021 Global Cities Report, Kearney. 2021. Available online: https://www.kearney.com/global-cities/2021 (accessed on 30 May 2021).

62. Taylor, P.J.; Derudder, P.N.B.; Hoyler, M.; Huang, J.; Lu, F.; Pain, K.; Witlox, F.; Yang, X.; Bassens, D.; Shen, W. Measuring the World City Network: New Results and Developments. GaWC Research Bulletin 300. Available online: https://www.lboro.ac.uk/ gawc/rb/rb300.html (accessed on 1 February 2022).

63. Stadelbauer, J. Megacities as a Conflict Space. Global City: Theory and Reality. Moscow. 2007. Available online: http://www. demoscope.ru/weekly/2008/0343/analit04.php (accessed on 30 May 2021).

64. Achkasov, V.A. "Global Cities" Facing the Challenges of Globalization. Global Horizons of Human Rights, Culture and Identity, Politeks. 2013. Available online: https:/ / cyberleninka.ru/article/n/globalnye-goroda-pered-vyzovami-globalizatsii (accessed on 30 August 2021).

65. Kraas, F. Megacities as Global Risk Areas. In Urban Ecology; Springer: Boston, MA, USA, 2008; pp. 583-596. [CrossRef]

66. Churchill, A.; Lea, J.P.; Courtney, J.M. Cities in conflict. In Studies in the Planning and Management for Asian Cities; World Bank: Washington, DC, USA, 1985.

67. Pelling, M. The Vulnerability of Cities: Natural Disasters and Social Resilience; Taylor \& Francis: London, UK, 2003 ; ISBN 1-853838292.

68. Musin, A. Analysis of Existing International Transport Corridors Passing through Territories of the Member States; Analytical Report; Department of Transport and Infrastructure of the Eurasian Economic Commission: Moscow, Russia, 2019.

69. Transport Strategy Central Asia Regional Economic Cooperation (CAREC) 2030; Asian Development Bank: Mandaluyong City, Philippines, 2020; ISBN 978-92-9262-012-7.

70. Strengthening the Capacity of Landlocked Developing Countries (LLDCs) under the Belt and Road Initiative to Design and Implement Policies that Promote Transport Connectivity for the Achievement of the SDGs; Project PDF-SDG-2018-07; UN-OHRLLS: New York, NY, USA, 2020; project PDF-SDG-2018-07; 
71. Eurasian Transport Links. Report Phase II, UNECE, New York and Geneva. 2012. Available online: https://unece.org/DAM/ trans/main/eatl/docs/EATL_Report_Phase_II-Ru.pdf (accessed on 30 July 2021).

72. Transport Links between Europe and Asia. European Conference of Ministers of Transport, ECMT. 2006. Available online: https:/ / www.itf-oecd.org/sites/default/files/docs/06europe-asiaru.pdf (accessed on 30 July 2021).

73. Vinokurov, E.Y.; Lobyrev, V.G.; Tikhomirov, A.A.; Tsukarev, T.V. ранспортные коридоры шелкового пути: анализ барьеров и рекомендации по направлению инвестиций; Доклад 2018; Центр интеграционных исследований Евразийского банка развития: Almaty, Kazakhstan, 2018; ISBN 978-5-906157-44-7.

74. Hildyard, N.; Sol, X. How Infrastructure is Shaping the World. A Critical Introduction to Infrastructure Mega-Corridors. Counter Balance. 2017. Available online: http:/ / www.thecornerhouse.org.uk/resource/how-infrastructure-shaping-world (accessed on 30 September 2021).

75. Status of the Pan-European Transport Corridors and Transport Area: Developments and activities in 2000 and 2001 : Final report. Transmitted by TINA and the European Commission. 2002. Available online: https://digitallibrary.un.org/record/467604 (accessed on 30 September 2021).

76. Makarova, I.; Shubenkova, K.; Mavrin, V.; Buyvol, P.; Gabsalikhova, L.; Mukhametdinov, E. International Transport Corridors: Impact on Territorial Development. Adv. Econ. Bus. Manag. Res. 2019, 131, 654-662. [CrossRef]

77. Regmi, M.B.; Hanaoka, S. Assessment of intermodal transport corridors: Cases from North-East and Central Asia. Res. Transp. Bus. Manag. 2012, 5, 27-37. [CrossRef]

78. Šakalys, R.; Batarlienè, N. Research on Intermodal Terminal Interaction in International. Transp. Corridors. Procedia Eng. 2017, 187, 281-288. [CrossRef]

79. De Langen, P.W.; Figueroa, D.M.L.; Van Donselaar, K.H.; Bozuwa, J. Intermodal connectivity in Europe, an empirical exploration. Res. Transp. Bus. Manag. 2017, 23, 3-11. [CrossRef]

80. SteadieSeifi, M.; Dellaert, N.P.; Nuijten, W.; Van Woensel, T.; Raoufi, R. Multimodal freight transportation planning: A literature review. Eur. J. Oper. Res. 2014, 233, 1-15. [CrossRef]

81. Albrechts, L.; Tasan-Kok, T. Corridor and Axis Development. Int. Encycl. Hum. Geogr. 2009, 298-304. [CrossRef]

82. Albrechts, L.; Coppens, T. Megacorridors: Striking a balance between the space of flows and the space of places. J. Transp. Geogr. 2003, 11, 215-224. [CrossRef]

83. De Vries, J.; Priemus, H. Megacorridors in North-west Europe: Issues for Transnational Spatial Governance. J. Transp. Geogr. 2003, 11, 225-233. [CrossRef]

84. Singh, S. Urbanisation: From Mega-Cities, Mega-Regions, Mega-Corridors and Mega-Slums to Mega Opportunities. In New Mega Trends; Palgrave Macmillan: London, UK, 2012; pp. 61-80. [CrossRef]

85. Pell, C. Megalopolis Unbound: The Supercity and the Transportation of Tomorrow; Praeger: New York, NY, USA, 1966.

86. Castells, M. The Informational City: Information Technology, Economic Restructuring, and the Urban-Regional Process; Annals of the Association of American Geographers: Oxford, UK, 1992; ISBN 0631179372.

87. Tian, L.; Xu, G.; Fan, C.; Zhang, Y.; Gu, C.; Zhang, Y. Analyzing Mega City-Regions through Integrating Urbanization and Eco-Environment Systems: A Case Study of the Beijing-Tianjin-Hebei Region. Int. J. Environ. Res. Public Health 2019, 16, 114. [CrossRef] [PubMed]

88. Tonkoy, I.; Inshakova, O. Strategies of Settlement of the Future of Russia in the Context of the Dynamics of Space Consideration Tendencies in the Conditions of Globalization. Archit. Mod. Inf. Technol. 2020, 4, 266-280. [CrossRef]

89. Vershinina, I. Jan Gottman's concept of megalopolis. Moscow State University Bulletin Series 18. Sociol. Political Sci. 2019, 25, 36-48. [CrossRef]

90. Brunet, R. Lignes de Force de L'espace Européen. Mappemonde, 2002, 66(2002.2). Available online: http://www.mgm.fr/PUB/ Mappemonde/M202/Brunet.pdf (accessed on 30 September 2021).

91. Mumford, L. The culture of cities. In A Harvest/HBJ Book; Harcourt Brace Jovanovich: San Diego, CA, USA; New York, NY, USA; London, UK, 1970.

92. Mumford, L. The City in History: Its Origins, Its Transformations, and Its Prospects; Harcourt, Brace \& World: New York, NY, USA, 1961.

93. Geddes, P. Cities in Evolution: An Introduction to the Town Planning Movement and to the Study of Civics; Williams: London, UK, 1915.

94. Baigent, E. Patrick Geddes, Lewis Mumford and Jean Gottmann: Divisions over 'megalopol is'. Prog. Hum. Geogr. 2004, 28, 687-700. [CrossRef]

95. Novoseltseva, A.S. Key functions of megacities in the global economy: Systematic research. Bull. Volgogr. State Univ. 2011, 9, 71-77. Available online: https:/ / cyberleninka.ru/article/n/klyuchevye-funktsii-megapolisov-v-globalnoy-ekonomike-sistemnostissledovaniya (accessed on 30 May 2021).

96. Global Cities Index Kearney; International Consulting Company A.T. Kearney and the Chicago Council on Global Affairs: Chicago, IL, USA, 2021.

97. Kolyasnikov, V.; Spiridonov, V. Modern Theory and Practice of Urban Planning: Settlement Spatial Development; Architecton: Yekaterinburg, Russia, 2016; ISBN 978-5-7408-0180-3.

98. Spiridonov, V. The Evolution of the Concepts of Architectural and Planning Development of Resettlement Systems, Dissertation; Architecton: Yekaterinburg, Russia, 2012. 
99. Pertsik, E.N. Cities of the World: The Geography of World Urbanization; International relations: Moscow, Russia, 1999; ISBN 5-7133-0965-7.

100. Doi, T. Japan Megalopolis: Another Approach. Ekistics 1968, 26, 96-99.

101. Hildyard, N. Infrastructure Corridors, Frontier Finance and the Vulnerabilities of Capital; Oxford University Press: Oxford, UK, 2016.

102. CAREC Transport Strategy 2030; The Asian Development Bank: Mandaluyong, Philippines, 2020. [CrossRef] 